\title{
VALIDASI PENGEMBANGAN MODUL FISIKA DASAR BERBASIS PROBLEM BASED INSTRUCTION UNTUK MAHASISWA STKIP PGRI SUMATERA BARAT
}

\author{
Iing Rika Yanti ${ }^{(1)}$ dan Lince Meriko ${ }^{(2)}$ \\ ${ }^{(1)}$ Prodi Pendidikan Fisika STKIP PGRI Sumatra Barat \\ ${ }^{(2)}$ Prodi Pendidikan Biologi STKIP PGRI Sumatra Barat \\ Email iing1408@gmail.com \\ http://dx.doi.org/10.22202/jrfes.2014.v1i1.1184
}

\begin{abstract}
Basic physics is a subject in STKIP PGRI West Sumatra. To support this course required instructional materials in the form of modules. Teaching materials developed a module-based Problem Based Instruction able to make students more active and critical thinking and skilled in problem solving basic physics. Students are expected to play an active role in solving the problem. As for the characteristics of the problems presented in this Instruction problem based learning should be interesting and challenging students to analyze and solve. This study aimed to validate the development of module-based Basic Physics Problem Based Instruction valid, practical, and effective. This type of research is research \& development (research and development) using a model of Plomp is passing through stages: (1) the initial investigation (preliminary research), (2) design and realization (prototyping phase), and (3) testing and assessment ( assessment phase). In the preliminary stages of research analyzed the curriculum, students analysis, and analysis of the concept. At the stage of prototyping phase is to design a module for the course Physics. Additionally performed formative evaluation measures that include selfevaluation, prototyping (expert reviews, one-to-one and small group), as well as fieldtest. Stages assessment phase carried out testing of the module. The research data was obtained through basic physics module validation sheet.
\end{abstract}

Keywords: Validation, modules, problem-based instruction, basic physics

\section{Abstrak}

Fisika dasar merupakan mata kuliah di STKIP PGRI Sumatera Barat. Untuk mendukung perkuliahan ini dibutuhkan bahan ajar berupa modul. Bahan ajar yang dikembangkan merupakan modul yang berbasis Problem Based Instruction mampu untuk membuat mahasiswa lebih aktif dan berfikir secara kritis serta terampil dalam pemecahan masalah fisika dasar. Mahasiswa diharapkan dapat berperan aktif dalam memecahkan masalah. Adapun karakteristik masalah yang disajikan dalam pembelajaran Problem Based Instruction ini harus menarik dan menantang mahasiswa untuk menganalisis dan memecahkannya. Penelitian ini bertujuan untuk menvalidasi pengembangan modul Fisika Dasar berbasis Problem Based Instruction yang valid, praktis, dan efektif.

Jenis penelitian yang digunakan adalah penelitian pengembangan (research and development) menggunakan model Plomp yaitu yang melewati tahapan: (1) investigasi awal (preliminary research), (2) perancangan dan realisasi (prototyping phase), dan (3)uji coba dan penilaian (assessment phase). Pada tahap preliminary research dilakukan analisis kurikulum, analisis mahasiswa, dan analisis konsep. Pada tahap prototyping phase dilakukan perancangan modul untuk mata kuliah Fisika Dasar. Selain itu dilakukan langkah formative evaluation yang meliputi selfevaluation, prototyping (expert reviews, one-to-one, dan small group), serta fieldtest. Tahapan assessment phase dilakukan pengujian terhadap modul. Data penelitian ini diperoleh melalui lembar validasi modul fisika dasar.

Keywords : Validasi, modul, problem based instruction, fisika dasar 


\section{PENDAHULUAN}

Dewasa ini, teknologi berkembang begitu pesat. Banyak produk teknologi yang dapat dinikmati dalam bentuk peralatan sederhana, sampai yang canggih, peralatan rumah tangga sampai dengan teknologi informasi, sehingga sudah banyak kemudahan-kemudahan yang dirasakan. Perkembangan teknologi merupakan indikator kemajuan suatu bangsa, bangsa yang maju ditandai oleh kemajuan teknologinya. Kemajuan teknologi dipengaruhi oleh perkembangan sains. Antara sains dan teknologi, ibarat dua sisi mata uang yang bergerak dengan kecepatan tinggi. Fisika merupakan cabang ilmu yang memiliki kontribusi dominan terhadap perkembangan teknologi. Fisika dasar merupakan salah satu mata kuliah program studi fisikamenunbuhkan pola pikir kritis pada mahasiswa. Oleh sebab itu, penguasaan fisika haruslah memadai

Pembelajaran fisika menurut [1] melibatkan banyak aspek dan aktivitas. Prosesproses yang dialami mahasiswa dalam belajar, meliputi: internalisasi nilai-nilai, menilai diri sendiri dan menentukan pilihan melalui belajar fisika, karir fisika, menerapkan pengetahuan dan keterampilan ilmiah dalam kehidupan sehari-hari.

Harapan pembelajaran Fisika Dasar yang ideal adalah pencapaian dalam silabus yang dijabarkan berdasarkan Stansar Kompetensi dan Kompetensi Dasar menjadi indikator yang harus dicapai dalam setiap pembelajaran. Salah satu tuntutan kurikulum yaitu pembelajaran yang berpusat pada mahasiswa, dosen tidak lagi subjek pembelajaran, melainkan mahasiswalah yang menjadi subjek. Dosen berperan sebagai fasilitator, motivator dan salah satu alternatif sumber belajar. Dosen mendisain bahan ajar yang sesuai dengan tuntutan kurikulum yang dapat membelajarkan mahasiswa sehingga mahasiswa mendapat kompetensi yang harus dikuasainya. Apabila dosen belum membuat bahan ajar, dapat dipastikan bahwa pembelajaran yang dilakukan adalah teacher center.

Kenyataan yang terjadi di lapangan hasil belajar fisika dasar mahasiswa masih rendah.Rendahnya hasil belajar mahasiswa yang terdapat di lapangan disebabkan oleh beberapa hal, yaitu dalam proses pembelajaran, mahasiswa belum dilibatkan secara aktif dalam mencari fakta, konsep, dan prinsip yang dapat diterapkan untuk memecahkan masalah-masalah dalam kehidupan sehari-hari. Di lain pihak, mahasiswa yang telah memahami konsep fisika dasar belum mampu berpikir kritis sehhingga dapat menerapkan konsep itu di dalam kehidupan mereka sehari-hari. Serta bahan ajar yang dirancang dosen belum sesuai dengan keadaan mahasiswa serta karakteristik kampusnya.

Pembelajaran merupakan proses pengembangan berbagai komponen secara sistematis dan sistemik yang meliputi berbagai komponen, yaitu dosen, perangkat pembelajaran, bahan ajar, mahasiswa, dan proses pembelajaran strategi. Ini berarti bahwa perangkat pembelajaran merupakan komponen proses pengembangan pembelajaran yang perlu dimiliki dosen. Untuk meningkatkan pembelajaran fisika dasar di kelas, diperlukan bahan ajar yang berkualitas. Jika diamati pada buku teks fisika dasar mahasiswa, sebagian materi yang disajikan masih banyak yang tidak sesuai dengan pencapaian indikator yang diharapkan, ini menyebabkan mahasiswa kesulitan mempelajari fisika dasar.

Berdasarkan uraian di atas, terlihat jelas bahwa untuk meningkatkan minat mahasiswa pada pembelajaran fisika yang akhirnya diharapkan dapat meningkatkan hasil belajarnya adalah dengan membuat bahan ajar yang menggunakan model pembelajaran yang berpusat pada mahasiswa. Dosen memfasilitasi kebutuhan belajar mahasiswa tanpa mendominasi proses belajar mahasiswa. Adapun model pembelajaran yang dapat digunakan adalah Problem Based Instruction (PBI) yang terdiri atas lima langkah yang dimulai dengan dosen memperkenalkan 
mahasiswa dengan situasi masalah dan diakhiri dengan penyajian dan analisis hasil kerja mahasiswa. Dengan demikian, masalah yang dimunculkan pada awal pembelajaran merupakan kakteristik PBI.

Dosen dalam PBI bertindak sebagai fasilitator bukan sebagai penyampai informasi.Mahasiswa diharapkan dapat berperan aktif dalam memecahkan masalah.Adapun karakteristik masalah yang disajikan dalam pembelajaran PBI ini harus menarik dan menantang mahasiswa untuk menganalisis dan memecahkannya.Tahapantahapan model pembelajaran adalah memperkenalkan mahasiswa dengan situasi masalah, mengorganisasikan mahasiswa dalam kelompok belajar, mahasiswa melakukan kegiatan penyelidikan guna mendapatkan konsep untuk menyelesaikan masalah kemudian membuat karya, mempresentasikannya dan diakhiri dengan penyajian serta analisis evaluasi hasil dan proses.

Berdasarkan uraian di atas, dapat diketahui bahwa penggunaan model PBI dalam pembelajaran dapat mendorong mahasiswa untuk memecahkan masalahmasalah fakta, konsep, dan prinsip dalam pembelajaran fisika dasar. Pembelajaran ini juga menjadikan mahasiswa untuk berfikir secara kritis dan keterampilan dalam pemecahan masalah.Oleh karena itu perlu dirancang dan dikembangkan bahan ajar dalam bentuk modul yang valid.

Berdasarkan latar belakang di atas, maka dapat dirumuskan permasalahan sebagai berikut: "Bagaimana modul fisika dasar dengan menggunakan model PBI yang valid?"

Penelitian ini bertujuan untuk mengembangkan modul Fisika Dasar menggunakan model PBI sehingga memudahkan mahasiswa dan dosen dalam melakukan proses pembelajaran fisika dasar. Secara khusus penelitian ini bertujuan untuk mengembangkan modul model PBIyang valid pada Fisika Dasar

Penelitian ini diharapkan dapat memberikan manfaat sebagai berikut:
1. modul yang dihasilkan diharapkan dapat digunakan oleh dosen dalam upaya meningkatkan dan mengembangkan pola fikir mahasiswa;

2. modul yang dihasilkan diharapkan dapat digunakan oleh dosen dalam menerapkan pembelajaran Fisika Dasar yang dapat mengembangkan kemampuan penguasaan dan penerapan konsep fisika dasar oleh mahasiswa;

3. sebagai salah satu acuan bagi rekan dosendosen dan peniliti lainnya untuk mengembangkan modul model PBI pada mata kuliah Fisika lainnya.

\section{METODOLOGI PENELITIAN}

Berdasarkan rumusan masalah yang telah dikemukakan maka jenis penelitian yang dilakukan adalah penelitian pengembangan (Research and Development). Menurut [2] "R\&D adalah metode pelitian yang digunakan untuk menghasilkan produk tertentu, dan menguji keefektifan produk tersebut". Selain itu [3] penelitian pengembangan adalah suatu proses dan langkah-langkah untuk mengembangkan suatu produk baru atau menyempurnakan produk yang telah ada. Dalam hal ini dikembangkan suatu modul pembelajaran fisika dasar dengan menggunakan model Problem Based Instruction (PBI) yang valid, praktis, dan efektif. Penelitian pengembangan yang dilakukan mengacu pada model pengembangan perangkat pembelajaran oleh [4] yaitu yang melewati tahapan: (1) investigasi awal (preliminary research), (2) perancangan dan realisasi (prototyping phase), dan (3)uji coba dan penilaian (assessment phase).

Kegiatan pengembangan ini dimulai dengan investigasi awal, kemudian merancang dan mengembangkan modul, setelah itu dilakukan uji coba dan penilaian sehingga dihasilkan modul yang praktis dan efisien.

Langkah-langkah rancangan pengembangan modul diatas dapat dirinci sebagai berikut : 
a. Fase investigasi awal (preliminary research)

Pada tahap ini dilakukan analisis awal atau identifikasi masalah, analisis kebutuhan dan analisis konsep atau isi materi, dan pengkajian literatur yang diperlukan dalam pembelajaran.

Analisis konsep bertujuan untuk menentukan isi dan materi pelajaran yang dibutuhkan dalam pengembangan perangkat pembelajaran.Dalam analisis konsep peneliti melakukan identifikasi terhadap konsep esensial dari materi fisika dasar yaitu besaran dan satuan, kinematika, dinamika, usaha dan energi, momentum linier, fluida serta konsep suhu dan kalor.

Selanjutnya, dilakukan analisis terhadap karakteristik mahasiswa untuk menentukan model pengembangan perangkat pembelajaran yang akan digunakan. Selain itu, peneliti juga melakukan kajian terhadap literatur yang tersedia.

b. Fase Perancangan dan Realisasi (prototyping phase)

Pada tahap ini dilakukan perumusan/perancangan terhadap modul.Rancangan ini merujuk pada panduan pengembangan bahan ajar yang dikeluarkan oleh [5]. Dalam perancangan bahan ajar melewati beberapa langkah, antara lain : (1) mengkaji kesesuaian materi yang akan disajikan dalam bahan ajar dengan standar kompetensi dan kompetensi dasar yang terdapat dalam kurikulum, (2) menentukan kedalaman materi dan ruang lingkup bahan ajar, (3) menentukan urutan bahan ajar, (4) menentukan jenis perlakuan yang akan diberikan terhadap bahan ajar, (5) menentukan sumber materi pembelajaran.

Setelah tahap perancangan modul yang dikembangkan selesai, dilakukan perencanaan awal secara keseluruhan. Perencaan awal dilakukan dengan penulisan, penelaahan dan pengeditan modul yang disusun. Perancangan perangkat pembelajaran dibuat sesuai dengan indikator yang ditatapkan dan berdasarkan format yang disesuaikan dengan kebutuhan peneliti.
Pada tahap ini dilakukan formative evaluation yang meliputi selfevaluation, prototyping (expert reviews, one-to-one, dan small group), serta fieldtest. Adapun alur desain formative evaluation sesuai dengan [6] seperti ditunjukkan pada gambar 1

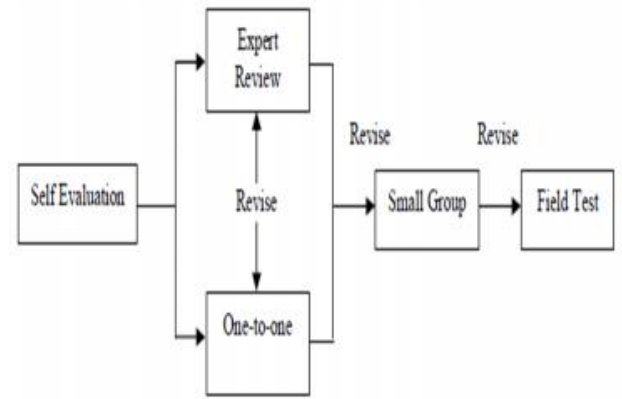

Gambar 1. Alur Desain formative evaluation

\section{1) Self Evaluation}

Pada tahap ini dilakukan pendesainan modul yang akan dikembangkan. Tahapan ini dilakukan berdasarkan hasil analisis awal atau identifikasi masalah, analisis kebutuhan dan analisis konsep atau isi materi, dan pengkajian literatur yang diperlukan dalam pembelajaran

2) Expert Review

Pada tahap expert review, dilakukan pencermatan terhadap modul yang telah didesain, penilaian dan evaluasi oleh pakar.Pakar-pakar tersebut menelaah konten, konstruk, dan bahasa dari masingmasing prototipe.Saran-saran para pakar digunakan untuk merevisi modul yang dikembangkan.Pada tahap ini, tanggapan dan saran dari para pakar (validator) tentang desain yang telah dibuat ditulis pada lembar validasi sebagai bahan revisi dan menyatakan bahwa apakah desain ini telah valid atau belum.

Kegiatan validasi ini dilakukan untuk mendapatkan masukan terhadap keseluruhan isi materi yang terdapat dalam rancangan modul. Kemudian validasi dilihat pada aspek design pembelajaran, bertujuan untuk mendapatkan kesesuaian model dan bentuk rancangan dari perangkat pembelajaran yang dikembangkan. Bagian utama yang divalidasi adalah kesesuaian 
$\mathrm{KD}$, indikator, kebenaran konsep dan bahasa yang digunakan.Masukan dari validator digunakan untuk memperbaiki dan merevisi perangkat pembelajaran yang dikembangkan.

3) One-to-one

Pada tahap one-to-one, dilakukan ujicoba desain yang telah dikembangkan kepada Mahasiswa dan dosen yang menjadi tester.Hasil dari pelaksanaan ini digunakan untuk merevisi desain yang telah dibuat.

4) Small group

Hasil revisi dari telaah expert dan kesulitan yang dialami pada saat uji coba pada Uji coba pertama dijadikan dasar untuk merevisi modul tersebut, kemudian hasilnya diujicobakan pada small group.Hasil dari pelaksanaan ujicoba ini selanjutnya digunakan untuk revisi sebelum dilakukan ujicoba pada tahap field test.Setelah dilakukan revisi modul berdasarkan saran dan komentar mahasiswa pada small group, diperoleh hasil analisis terhadap modul tersebut.

\section{5) Field Test}

Hasil revisi small group selanjutnya diujicobakan ke subjek penelitian.Uji coba dalam hal ini merupakan uji lapangan atau field test.Modul yang telah diujicobakan pada uji lapangan haruslah modul yang telah memenuhi kriteria kualitas yang meliputi validitas, kepraktisan, dan efektivitas.

c. Fase Penilaian (assessment phase)

Tahap ini dilakukan untuk mengetahui apakah modul dapat digunakan untuk mencapai tujuan yang efektif dalam meningkatkan kualitas dan prestasi belajar mahasiswa.

\section{HASIL DAN PEMBAHASAN}

Berdasarkan investigasi awal yang dilakukan terhadap mahasiswa maka dilakukan perancangan modul dengan menggunakan model PBI. Beberapa tahap yang dihasilkan dalam proses perancangan modul pembelajaran. Modul yang dibuat adalah sebuah bahan ajar yang di tulis dengan tujuan agar mahasiswa dapat belajar secara mandiri tanpa atau dengan bimbingan dosen. Modul berisi petunjuk belajar, kompetensi yang akan dicapai, isi materi, informasi pendukung, evaluasi yang dikaitkan dengan komponen PBI [7]yaitu Fase 1 Orientasi pada masalah, fase 2 mengorganisasi untuk pemecahan masalah, fase 3 penyelidikan individu maupun kelompok, fase 4 menyajikan hasil karya, dan fase 5 evaluasi proses pemecahan masalah.

Karakteristi modul yang dikembangkan dalam penelitian adalah :

1. Terlebih dahulu diawal modul diberikan deskripsi, petunjuk dan penggunaan modul agar sebelum menggunakan modul mahasiswa lebih terarah dalam belajar

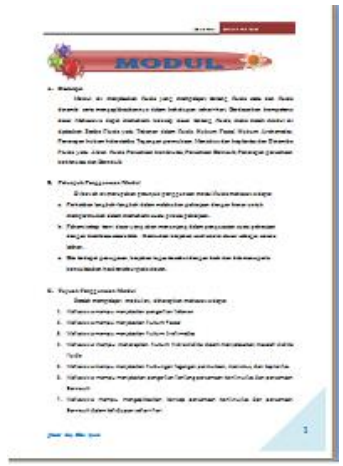

2. Materi yang disampaikan berdasarkan sintaks PBI yang ada

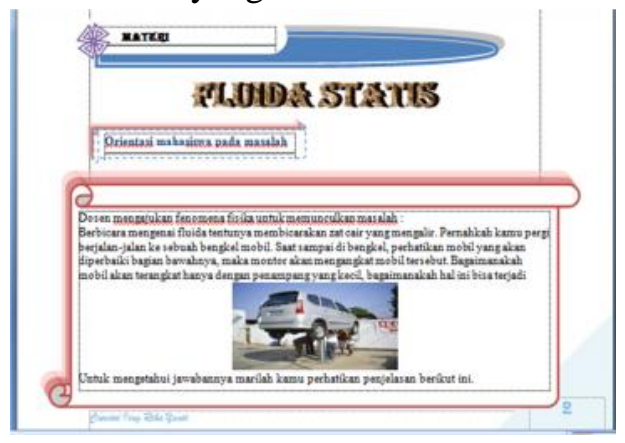

Modul yang telah dirancang selanjutnya di evaluasi dan dinilai oleh pakar atau teman sejawat.Pakar-pakar tersebut menilai validasi isi, konstruk, dan bahasa.Saran-saran dari para 
pakar atau teman sejawat digunakan sebagai acuan untuk merevisi modul yang dikembangkan.Bagian utama yang divalidasi adalah kesesuaian KD, kebenaran konsep dan bahasa yang digunakan.Masukan dari validator digunakan untuk memperbaiki dan merevisi modul yang dikembangkan sehingga dihasilkan modul yang valid.

Berdasarkan hasil validasi pertama dari validator, maka diperoleh saran terhadap modulyang dikembangkan.

Saran yang diberikan para pakar memaparkan saran-saran yang perlu direvisi terhadap modul. Saran validator yang belum memberikan gambar-gambar pendukung maka dilakukan revisi dengan memeberikan tambahan gambar agar mahasiswa lebih mengerti dengan pernyataan yang dimaksud dalam modul. Kemudian saran validator mengenai penggunaan komposisi warna yang kurang maka dilakukan revisi dengan menggunakan komposisi warna yang jelas dan menarik bagi mahasiswa.Setelah saran yang diberikan oleh validator direvisi maka dilakukanlah validasi kedua.

Berdasarkan hasil validasi yang didapatkan, maka dapat disimpulkan bahwa modul yang dikembangkan secara keseluruhan sudah sangat valid dengan nilai rata-rata validasi $92 \%$, Dengan demikian, modul yang dikembangkan dapat digunakan dalam pembejaran di kampus .

Kevalidan perangkat pembelajaran yang dihasilkan dapatdiketahui dengan melakukan validasi modul oleh validator.Hasil validasi dianalisis untuk mengetahui validitas modul baik dari segi isi maupun kostruksinya.

Pengujian validitas konstruksi dan validitas isi dapat dibantu dengan menggunakan kisi-kisi instrumen yang terdiri dari variabel yang diteliti sebagai tolak ukur dan nomor butir pertanyaan atau pernyataan yang telah dijabarkan dari indikator, sehingga pengujian validitas dapat dilaksanakan dengan mudah dan sistematis.

Hasil penilaian validator menunjukkan modul telah memenuhi syarat kelayakan isi meliputi kesesuaian dengan kurikulum, struktur keilmuan, aktual, dan keluasan materi.Modul yang dikembangkan menyajikan topik yang sesuai dengan tuntutan kompetensi dasar yang telah dirumuskan.Modul juga menyajikan informasi singkat ataupun pertanyaan yang sesuai dengan deskripsi materi fluida. Selain itu, orientasi masalah yang disajikan dalam modul dikaitkan dengan materi yang dibahas dan kontekstual dengan yang dihadapi mahasiswa yang merupakan ciri dari PBI.Selain itu permasalahan yang diberikan merupakan permasalahan fisika yang dapat membabgun daya pikir mahasiswa menjadi kritis dan inovatif.Modul juga telah memiliki daftar rujukan yang jelas.

Penilaian validator menunjukkan bahwa modul juga sudah sesuai dengan konsepkonsep pembelajaran model PBI. Di samping itu tampilan gambar, huruf dan pewarnaan juga menarik bagi pembaca.Penggunaan bahasa menurut penilaian validator juga sudah mengacu pada penggunaan Ejaan Yang Disempurnakan (EYD).

Hasil validasi perangkat pembelajaran yang dikembangkan memiliki persentase nilai validasi modul adalah $92 \%$ yang berkategorikan sangat valid.

\section{KESIMPULAN}

Berdasarkan hasil penelitian pengembangan modul Fisika dasar menggunakan PBI pada materi fluida, kegiatan yang sudah dilakukan adalah merancang modul berbasis PBI dan melakukan validasi terhadap modul tersebut.

\section{DAFTAR PUSTAKA}

[1] Supriyono, K. 2003. Strategi pembelajaran fisika.Malang : jurusan fisika UNM.

[2] Sugiyono. 2011. Metodologi Penelitian Penddikan Pendekatan Kuantitatif, Kualitatif, dan R\&D. Bandung: Alfabeta

[3]Sudjana, N. 2002. Penilaian Proses Hasil Belajar Mengajar. Bandung; Remaja Rosdakarya. 
[4] Plomp, Tjeerd. 2010. An Introduction to Educational Design Research. Enschede: University of Twente

[5] Departemen Pendidikan Nasional. 2008. Panduan Pengembangan Bahan Ajar. Departemen Pendidikan Nasional, Direktorat Jenderal Manajemen Pendidikan Dasar dan
Menengah, Direktorat Pembinaan Sekolah Meengah Atas.

[6] Tessmer, M. (1998). Planning and Conducting Formative Evaluations. Philadelphia: Kogan Page.

[7] Trianto. 2007. Model-model Pembelajaran Inovetif 